\title{
The Effect of Nitrogen Gas Cooling Which Is Used in Aluminium Extrusion Mold on Production Efficiency
}

\author{
Merve Ozcan*, Cemal Ozsut, Oguzhan Deveci, Gulbahar Bentesen \\ Zahit Alüminyum San. ve Tic. A.Ş., Adana, Turkey \\ Email: ^m.ozcan@zahit.com.tr
}

How to cite this paper: Ozcan, M., Ozsut, C., Deveci, O. and Bentesen, G. (2021) The Effect of Nitrogen Gas Cooling Which Is Used in Aluminium Extrusion Mold on Production Efficiency. Open Journal of Applied Sciences, 11, 414-421.

https://doi.org/10.4236/ojapps.2021.114030

Received: March 6, 2021

Accepted: April 11, 2021

Published: April 14, 2021

Copyright $\odot 2021$ by author(s) and Scientific Research Publishing Inc. This work is licensed under the Creative Commons Attribution-NonCommercial International License (CC BY-NC 4.0).

http://creativecommons.org/licenses/by-nc/4.0/

\begin{abstract}
It is aimed to investigate the efficiency of nitrogen gas cooling which is used in aluminium extrusion mold in this study. The exit temperature of extrusion profile increases depending on heat generated by friction and forming. This situation can cause to surface defects such as hot cracks and grain thickening after extrusion process. Cooling of the mold has a critical role in terms of dissipating heat close to the forming zone. Local internal cooling experiments were performed in the hot aluminium extrusion mold within the scope of this study. It has been obtained that exit temperature of the aluminium extrusion profile can be significantly reduced in experimental results. Also it was found that the reduction of press time $(\mathrm{s})$ and increase of press speed $(\mathrm{mm} / \mathrm{s})$. This paper focuses the effect of nitrogen gas cooling on extrusion mold for process efficiency. The extrusion parameters were performed for comparative analysis. Its obtained that process ensures efficiency.
\end{abstract}

\section{Keywords}

Aluminium Extrusion Mold, Cooling System, Production Efficiency

\section{Introduction}

Aluminium and its alloys continue to be preferred in wide application areas with an increasing accelaration in different industries due to their superior physical/ mechanical properties. The properties of thermal conductivity, non-flammable, inflammable, weldable also provide significant advantages as the engineering material. Aluminium and its alloys exhibit ease of processing and also its suitable for developing light materials [1]. Aluminium alloys can be categorized as a casting and wrought aluminium alloys according to forming method. The produc- 
tion process which belongs to casting aluminium products can be defined chemical composition design, homogenization, extrusion, thermal heat treatment and finally surface finishing. In plastic forming method, the hot billet is pressed at high pressure and temperature through profile holes in extrusion mold. Aluminium extrusion is the definition of the shaping a material by forcing to flow through a shaped hole in mold. While the machine equipment performs their functionality, the surfaces of the parts are exposed to higher stress and higher abrasive forces during extrusion process. When these stresses and forces exceed the surface strength limit of the material, stress cracks begin on the material surface [2]. Aluminium extrusion process is affected many different parameters. The process equipments have a critical role to ensure extrusion process efficiency. Aluminium extrusion mold is exposed to thermal and mechanical conditions. The billet is heated about $450^{\circ} \mathrm{C}-480^{\circ} \mathrm{C}$. The preheating of aluminium billet allows being easily formed aluminium and reducing of the press pressure. Then extrusion temperature arrives $500^{\circ} \mathrm{C}-520^{\circ} \mathrm{C}$ by thermomechanical effect which occur deformation that follows. This deformation also can be defined reduction of area when aluminium profile is formed out of the massive billet [3]. Wear resistance of extrusion mold which directly effect aluminium profile surface quality is very important. Also the change of the dimensions of aluminium extrusion profile can be defined possibility problems that arise from extrusion mold wear. The increase of energy requirement due to industrialization and developing technology in the aluminum production process as in different production industries make energy and process efficiency important. The way of the improving the surface of materials is coating method which enable to technically and economically advantage. Surface coating process is applied to improve strength of materials in different environmental conditions such as ceramic coating and nitriding [4]. Despite this coating technology is applied to extrusion steel mold, some technical problems can be observed both aluminium and mold surface during thermomechanical process. The extrusion speed is desired to increase for improving reporductivity in hot metal extrusion. However, the exit temperature of extrudate profile increases due to forming temperature and heat generated by by friction. This can cause surface defects such as hot cracks and grain thickening after extrusion. The design of the extrusion mold for the quality of the extruded aluminium product is very important point in the extrusion process. To ensure thermodynamic and tribological relationship has a critical role for controlling frictional behavior between mold surface and flowing material [5]. The restricted tolerance requirements are needed for minimizing variations that belong to surface and physical properties during extrusion process. Also it enables to heat distrubiton can be controlled in surface of mold and aluminium during thermomechanical process. The isothermal extrusion of aluminium has a critical role in aluminium surface properties. Marin M.M. et al., (2017) has been analyzed the influence of the temperature in the extrusion process. The influence of the temperature on the exit velocity was reported. Also it was reported that the load carry out the extrusion process is inversely proportional to the die and billet 
temperatures [6]. The temperature is generated by deformation and friction affect on mechanical properties of the aluminium profiles. The aluminium profile exit temperature variations might affect on aluminium mechanical properties and linearity of product shape. The exit temperature degree determines the microstructure, mechanical and surface quality of the aluminium profiles. Also the oxidation of aluminium surface is extremely sensitive to aluminium profile exit temperature [7]. Many experimental and simulations researchs were conducted about effect of different process paramaters on the exit velocity and temperature of the extruded aluminium profiles [8]. In this study, we have performed experimental studies of the extrusion process with nitrogen gas cooling system. To raise production efficiency by cooling the mold with nitrogen gas, the reduction of high oxidation will be one of the important output due to inert nature of nitrogen gas. It also aimed to increase the production capacity of extrusion press.

\section{Material and Methods}

\subsection{The Physics of Metal Flow}

The aluminium extrusion process enables to products that have a most complex cross-sectional shaped. The product quality directly is directly affected by many parameters such as mold design parameters, process operating conditions of the used alloys which has a different chemical composition. The material flow controlling of thin walled high strength profiles is one of the most challenges point in the extrusion process [9]. The optimal material flow conditions are required to heat balance of billet. Especially the extrusion of aluminium alloy which has a high strength is required high billet temperature. But the rise of billet heat can be cause to rising of the flow stress in material during extrusion process. This means is the higher press capability is needed. The aluminium billet which has a fluid characterization behaviour exhibit thermoelasto-viscoplastic behaviour when extruded at high temperature [10].

\subsection{The Extrusion Mold Design}

The extrusion process is a thermomechanical prosess that induces dimensional change of solid material by using temperature, time and applied force. Also thermomechanical process can be defined that simultaneous applying of temperature and deformation on the material for finening of microstructure and changing of the shape. The aluminium extrusion industry desire to speed and duplicate production because of increasing competition and demand. The production efficiency is desirabled to increase the extrusion speed. However the exit temperature of the aluminium profile increases. Thus the rising of exit cause to uncontrolled oxidation. Also the design of extrusion mold must enable to optimal metal flow temperature behaviour and homogeneous temperature distribution for obtaining desired aluminium profile surface quality. Design of extrusion and estimation of material flow and temperature distribution is very important issue 
because of cannot observed temperature and flow distribution in the mold during thermomechanical process. Some challenges can be arise because of uncontrolled physical process such as rise profile exit temperature, even if the process was be remarkably performed. Therefore, the aluminium extrusion industry require to improve technology capability. The demand and technical problems should be generated a solutions with using technology or maybe should set new process standards for production efficiency. The cooling system is one of method which ensures to isothermal process. The study is aimed to the generated temperature should be properly distribution on the material for isothermal extrusion process. The surface quality of profile surface and mold life can be ensured that the positioning of cooling channels on the extrusion mold to compensate temperature rising. Figure 1 shows the design of cooling channels which was entegreted in different extrusion molds.

\subsection{The Extrusion Mold Production Process}

The AISI2344 steel was used for production extrusion mold. The chemical composition of the AISI2344 steel is given Table 1. Turning, milling and grinding were performed respectively. The steel was first turned into a lathe by cutting the front/back sides of the mill and the milling process was completed with the threading process. Finally the extursion mold was completed by grinding of the outer corner and the grinding of the bearings. Figure 2 shows that the existing extrusion mold design and new design with cooling channels.
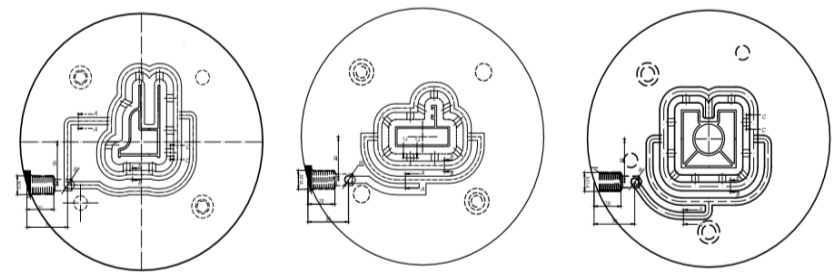

Figure 1. The design of extrusion mold with cooling channels.

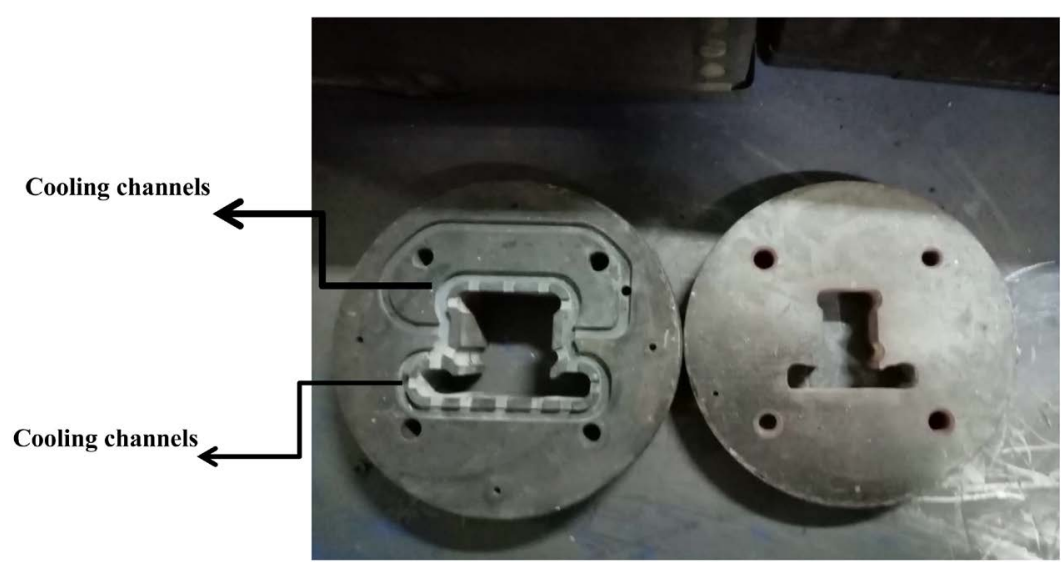

Figure 2. The final extrusion mold with cooling channels (left) and without cooling channels (right). 
Table 1. Chemical compositions of 2344 steel.

\begin{tabular}{ccccccccc}
\hline & C & Si & Mn & P & S & Cr & Mo & V \\
\hline$\%$ & 0.38 & 1.02 & 0.38 & 0.015 & 0.0005 & 5.11 & 1.26 & 0.92 \\
\hline
\end{tabular}

The cooling channels were located close to shaping zone in extrusion mold. The design of cooling channels doesn't prevent to material flow during extrusion process.

\section{Nitriding Process}

Gas nitriding was performed on the extrusion mold for surface treatment which aimed at improving the surface of materials. The AISI2344 steel was heated $520^{\circ} \mathrm{C}$ with ammonia gas $\left(\mathrm{NH}_{3}\right)$ and the diffusion temperature was kept at $520^{\circ} \mathrm{C}$ for 360 minutes, followed by cooling at $80^{\circ} \mathrm{C}$ and remaining about 120 minutes. Finally its completed nitrided process. The hardness value was obtained about 918 $\mathrm{HV}_{0.2}$ for samples with nitriding. Surface roughness tests was also performed for nitriding samples. Ra value was obtained about $1.481 \mu \mathrm{m}$.

\section{Results and Discussion}

\section{Experimental Studies}

The extrusion experiments was performed with different extrusion speed $(\mathrm{mm} / \mathrm{s})$ by using existing aluminium extrusion mold and new extrusion mold design for comparative analysis. Following tables represent data which are taken in different period show extrusion parameters during experimental studies. Process parameters including the profile exit temperature, press speed, press pressure and press time were studied in this study. We have also investigated the effect of the cooling system during extrusion. It can be clearly seen that increasing of production efficiency using by cooling system. This means that aluminium profiles can be product with high speed with cooling system not occur surface defects caused by generated temperature.

The performance of the cooling system was experimentally performed for molds which have a different geometry. The experimental studies which belong to Tables 2-4 were performed in extrusion press with 1400 tonnage. The numerical process parameters demonstrated that the cooling system directly affect on the reducing of aluminium profile exit temperature. Also it was no observed that any metal flow stress because of cooling channels on the extrusion mold. This experimental studies show that it is possible to increase of production efficiency using by cooling method. The numeric data which is represented in tables show that the profile exit temperature reduced with applied nitrogen cooling despite of press speed. The surface defects and hot cracks was analyzed basically extrusion speed $(\mathrm{mm} / \mathrm{s})$. It was observed that the size of hot cracks increased with increasing extrusion speed $(\mathrm{mm} / \mathrm{s})$ and offline cooling system. Figures 3-5 show the diagram of the extrusion parameters of different molds were performed in experimental studies. 


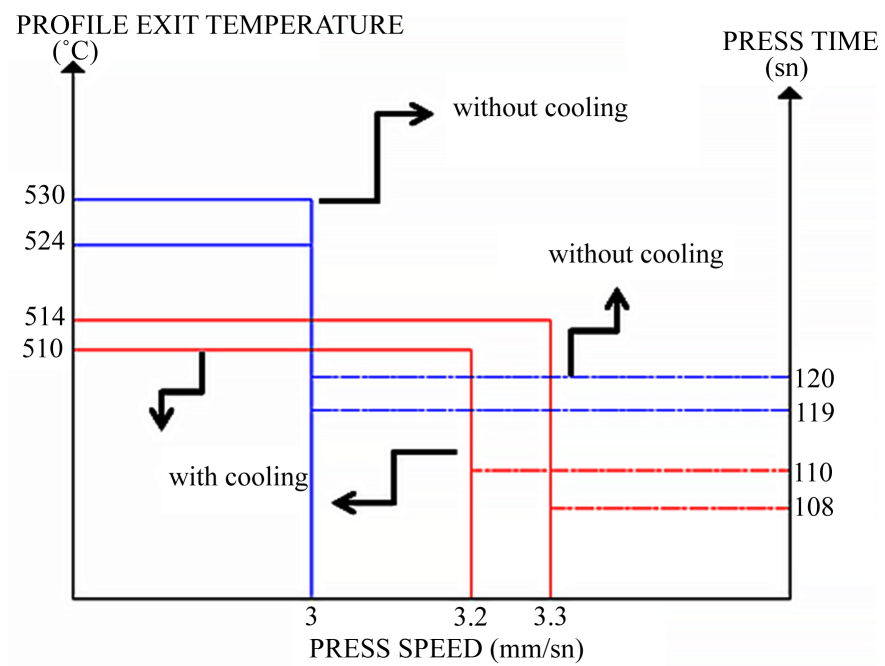

Figure 3. The diagram of the extrusion parameters of 6271 mold number.

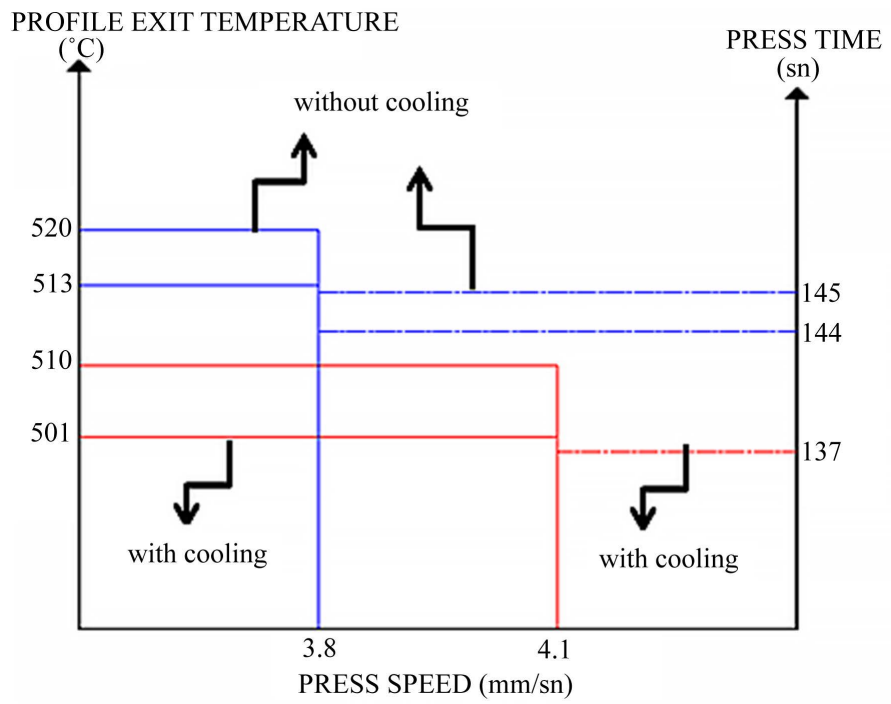

Figure 4. The diagram of the extrusion parameters of 4724 mold number.

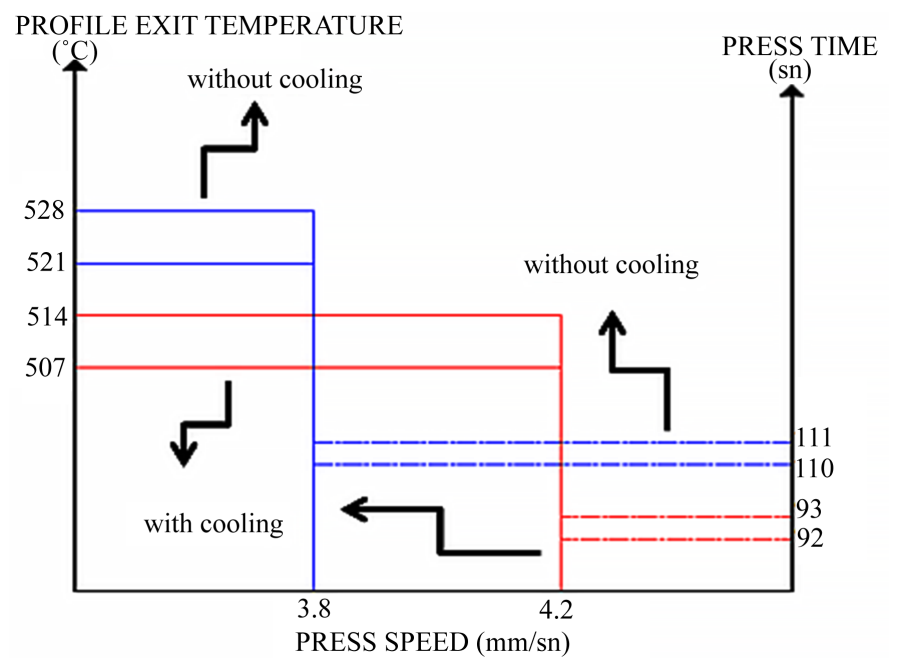

Figure 5. The diagram of the extrusion parameters of 2183 mold number. 
Table 2. Extrusion parameters with different methods.

\begin{tabular}{ccccccccc}
\hline $\begin{array}{c}\text { Die } \\
\text { Number }\end{array}$ & $\begin{array}{c}\text { Profil } \\
\text { number }\end{array}$ & $\begin{array}{c}\text { Billet } \\
\text { Length } \\
(\mathrm{mm})\end{array}$ & $\begin{array}{c}\text { Cooling } \\
\text { system }\end{array}$ & $\begin{array}{c}\text { Nitrogen } \\
\text { Gas } \\
(\%)\end{array}$ & $\begin{array}{c}\text { Profile exit } \\
\text { temperature } \\
\left({ }^{\circ} \mathrm{C}\right)\end{array}$ & $\begin{array}{c}\text { Press } \\
\text { speed } \\
(\mathrm{mm} / \mathrm{sn})\end{array}$ & $\begin{array}{c}\text { Press } \\
\text { pressure } \\
(\mathrm{bar})\end{array}$ & $\begin{array}{c}\text { Press } \\
\text { time } \\
(\mathrm{sn})\end{array}$ \\
\hline 6271 & 6271 & 360 & off & 0 & 530 & 3 & 204 & 120 \\
6271 & 6271 & 360 & off & 0 & 524 & 3 & 199 & 119 \\
6271 & 6271 & 363 & on & 20 & 510 & 3,2 & 196 & 110 \\
6271 & 6271 & 362 & on & 15 & 514 & 3,3 & 202 & 108 \\
\hline
\end{tabular}

Table 3. Extrusion parameters with different methods.

\begin{tabular}{|c|c|c|c|c|c|c|c|c|}
\hline $\begin{array}{c}\text { Mold } \\
\text { number }\end{array}$ & $\begin{array}{c}\text { Profil } \\
\text { number }\end{array}$ & $\begin{array}{c}\text { Billet } \\
\text { Length } \\
(\mathrm{mm})\end{array}$ & $\begin{array}{l}\text { Cooling } \\
\text { system }\end{array}$ & $\begin{array}{c}\text { Nitrogen } \\
\text { Gas } \\
(\%)\end{array}$ & $\begin{array}{l}\text { Profile exit } \\
\text { temperature } \\
\left({ }^{\circ} \mathrm{C}\right)\end{array}$ & $\begin{array}{c}\text { Press } \\
\text { speed } \\
(\mathrm{mm} / \mathrm{sn})\end{array}$ & $\begin{array}{c}\text { Press } \\
\text { pressure } \\
\text { (bar) }\end{array}$ & $\begin{array}{l}\text { Press } \\
\text { time } \\
(\mathrm{sn})\end{array}$ \\
\hline 4724 & 4724 & 540 & off & 0 & 520 & 3,8 & 207 & 145 \\
\hline 4724 & 4724 & 540 & off & 0 & 513 & 3,8 & 208 & 144 \\
\hline 4724 & 4724 & 540 & on & 30 & 510 & 4,1 & 201 & 137 \\
\hline 4724 & 4724 & 545 & on & 25 & 501 & 4,1 & 203 & 137 \\
\hline
\end{tabular}

Table 4. Extrusion parameters with different methods.

\begin{tabular}{|c|c|c|c|c|c|c|c|c|}
\hline $\begin{array}{c}\text { Mold } \\
\text { number }\end{array}$ & $\begin{array}{c}\text { Profil } \\
\text { number }\end{array}$ & $\begin{array}{c}\text { Billet } \\
\text { Length } \\
(\mathrm{mm})\end{array}$ & $\begin{array}{l}\text { Cooling } \\
\text { system }\end{array}$ & $\begin{array}{c}\text { Nitrogen } \\
\text { Gas } \\
(\%)\end{array}$ & $\begin{array}{c}\text { Profile exit } \\
\text { temperature } \\
\left({ }^{\circ} \mathrm{C}\right)\end{array}$ & $\begin{array}{c}\text { Press } \\
\text { speed } \\
(\mathrm{mm} / \mathrm{sn})\end{array}$ & $\begin{array}{c}\text { Press } \\
\text { pressure } \\
\text { (bar) }\end{array}$ & $\begin{array}{l}\text { Press } \\
\text { time } \\
(\mathrm{sn})\end{array}$ \\
\hline 2183 & 2183 & 450 & off & 0 & 528 & 3,8 & 196 & 110 \\
\hline 2183 & 2183 & 450 & off & 0 & 521 & 3,8 & 198 & 111 \\
\hline 2183 & 2183 & 450 & on & 8 & 514 & 4,2 & 202 & 93 \\
\hline 2183 & 2183 & 450 & on & 8 & 507 & 4,2 & 200 & 92 \\
\hline
\end{tabular}

When the blue line represents relationship between profile exit temperature and press speed and press time and press speed without cooling system, the red line represents relationship profile exit temperature and press speed and press time and press speed for using cooling system.

\section{Conclusion}

This study is aimed at providing a better understanding of the effect of cooling process on the profile exit temperature and production efficiency. The performance of the cooling system was experimentally performed for aluminium extrusion process in this study. We have investigated that effect of the local internal cooling in hot aluminium extrusion mold. It has proven that the exit temperature of the aluminium profiles can be remarkably reduced using by cooling system. The obtained numerical process parameters demonstrated that the cooling system directly affect on the production efficiency. We observed that if the cooling system is located close to shaped zone, the temperature can be distribution as a local. Also it was not observed that any surface defects with increasing extru- 
sion speed. This means that cooling channels don't prevent hot metal flow. Experimental studies with cooling system show that even if the extrusion speed increase, profile exit temperature doesn't increase. It has proved that the cooling of the mold has a critical role to distribute temperature close to shaping zone.

\section{Conflicts of Interest}

The authors declare no conflicts of interest regarding the publication of this paper.

\section{References}

[1] Mazzolani, F.M. (2004) Competing Issues for Aluminium Alloys in Structural Engineering. Progress in Structural Engineering and Materials, 6, 185-196. https://doi.org/10.1002/pse.178

[2] Olaseinde, O.A. and Adewuyi, B.O. (2016) Effect of Ceramic Powder Coatings on Low Carbon Steel. Federal University of Technology. https://doi.org/10.4236/msa.2016.75022

[3] Björk, T., Westergard, R. and Hogmark, S. (2001) Wear of Surface Treated Dies for Aluminium Extrusion-A Case Study. Wear, 249, 316-323. https://doi.org/10.1016/S0043-1648(01)00550-6

[4] Zhang, S. and Zhu, W. (1993) TiN Coating of Tool Steels: A Review. Journal of Materials Processing Technology, 39, 165-177. https://doi.org/10.1016/0924-0136(93)90016-Y

[5] Saha, P.K. (1998) Thermodynamics and Tribology in Alumium Extrusion. Wear, 218, 179-190. https://doi.org/10.1016/S0043-1648(98)00210-5

[6] Marin, M.M., Camacho, A.M. and Perez, J.A. (2017) Influence of the Temperature on AA6061 Aluminium Alloy in Hot Extrusion Process. Procedia Manufacturing, 13, 327-334. https://doi.org/10.1016/j.promfg.2017.09.084

[7] Bastani, A.F., Aukrust, T. and Brandal, S. (2011) Optimisation of Flow Balance and Isothermal Extrusion of Aluminium Using Finite-Element Simulations. Journal of Materials Processing Technology, 211, 650-667. https://doi.org/10.1016/j.jmatprotec.2010.11.021

[8] Zhou, J., Li, L., et al. (2004) Computer Simulated and Experimentally Verified Isothermal Extrusion of 7075 Aluminium through Continuous Ram Speed Variation. Journal of Materials Processing Technology, 146, 203-212. https://doi.org/10.1016/j.jmatprotec.2003.10.018

[9] Ayer, Ö., Bingöl, S. and Karakaya, İ. (2019) An Extrusion Simulation of an Aluminium Profile by Porthole Die. Vibroengineering PROCEDIA, 27, 139-144. https://doi.org/10.21595/vp.2019.20958

[10] Moe, P.T. (2005) Pressure and Strain Measurement during Hot Extrusion of Aluminium. PhD Thesis, Norwegian University of Science and Technology, Trondheim. 